\section{ACRL}

Preconferences

\title{
ACRL preconferences in San Francisco
}

\section{ACRL offers four opportunities for professional growth}

$\mathbf{A}$ CRL will host four preconferences prior to the ALA Annual Conference in San Francisco this June. The three section preconferences have been previously reported in CERL News and can be read about in more detail there; the issues are indicated in parentheses at the end of each description. Detailed information on each preconference is also available on the ACRL hompage at http:/ www.ala.org/acrl.html. Questions? Call (800) 545-2433, ext. 2514.

\section{How to register}

Download a registration form from the ACRL hompage at http://www.ala.org/acrl.html. Mail the completed form and payment to ACRL/ Name of Preconference, 50 E. Huron St., Chicago, IL 60611 or fax it to (312) 280-2520.

\section{RBMS: "Rereading the Past"}

ACRL's Rare Books and Manuscripts Section (RBMS) will offer "Rereading the Past: New Methodologies and Approaches to the History of the Book," June 24-27, at the Claremont Colleges in Southern California. The program will look at how research in the history of the book has developed since RBMS first looked at the subject in 1980. Scheduled speakers will include Robert Gross (College of William and Mary), Julian Roberts (Oxford University), Jeffrey Groves (Harvey Mudd College), Rosalind Remer (Moravian College), Steve Ferguson (Princeton University), and Ellen Dunlap (American Antiquarian Society).

Registration is $\$ 175$ for RBMS members, $\$ 210$ for nonmembers. Late registration, after May 23 , will be $\$ 225$ for members and $\$ 265$ for nonmembers. Additional fees will be charged for workshops.

Housing will be available in residence halls on the Claremont Colleges campuses as well as at the Claremont Inn. Claremont is located east of Los Angeles and is a 20-minute drive from the Ontario, California, airport. (CERL News, December 1996)

\section{IS: "Learning to Teach"}

ACRL's Instruction Section (IS) will offer "Learning to Teach: Workshops on Instruction," 8:30 a.m. $-5: 00$ p.m., Friday, June 27 , at the Berkeley Conference Center. Based on the publication of the same name, the preconference is a collection of training modules covering instruction fundamentals to help librarians from a variety of environments improve their teaching. Attendees are encouraged to adapt the workshops and use them for training at their own institutions. Participants will be able to attend four of these six sessions: "Contributions from the Psychology of Learning-Practical Implications for Teaching" (Joan Kaplowitz, UCLA); "Presentation Skills and Classroom Management" (Mary Popp, Indiana University); "Selecting a Teaching Technique" (Trudi Jacobson, SUNY-Albany); "Instruction in a Multicultural/ Multiracial Environment" (Karen Downing, University of Michigan, and Joseph Diaz, University of Arizona); "The One-Shot Lecture" (Esther Grassian, UCLA); and "Developing Effective Library Assignments" (Christina Woo, UC-Irvine).

Registration is $\$ 85$ for ACRL members, $\$ 120$ for ALA members and ACRL nonmembers, $\$ 75$ for library school students, and $\$ 200$ for nonALA/non-ACRL members. There will be a $\$ 35$ late fee for those registering after May 15. ( $C \& R L$ News, March 1997)

\section{WESS: "European Links"}

ACRL's Western European Specialists Section (WESS) will hold "European Links: Sources of Information in Western European Studies for Academic Libraries," June 26 and 27 at the Goethe House and an ALA conference location. The preconference will offer basic survival assistance-and even some advanced skills-to librarians responsible for choosing 
library materials from Western European countries. Speakers will include: Richard D. Hacken (Brigham Young University), Peter Allison (University of Connecticut), Heidi L. Hutchinson (UC-Riverside), Jeffry Larson (Yale University), Jeffrey Garrett (Northwestern University), Dan C. Hazen (Harvard University), Mary Jane
Parrine (Stanford University), and Mariann Tiblin (University of Minnesota).

Registration is $\$ 95$ for ACRL members, $\$ 130$ for ALA members, $\$ 50$ for library school students, and $\$ 185$ for non-ALA members. The deadline for registration is May 15. (CERL News, February 1997)

\section{"Telecommunications 101 for Librarians"}

Academic librarians are discovering that tions 101" will provide the practical backtheir service areas extend beyond campus ground information needed to understand and walls and, for many, across the address key information issues Atlantic. Their resources and services have expanded to include not only print but other formats such as multimedia and digital. Possessing the skills and knowledge to be a key player in defining and developing the campus information infrastructure is critically important to librarians. Understanding the telecommunications issues that will lead to decisions in applying technology and selecting

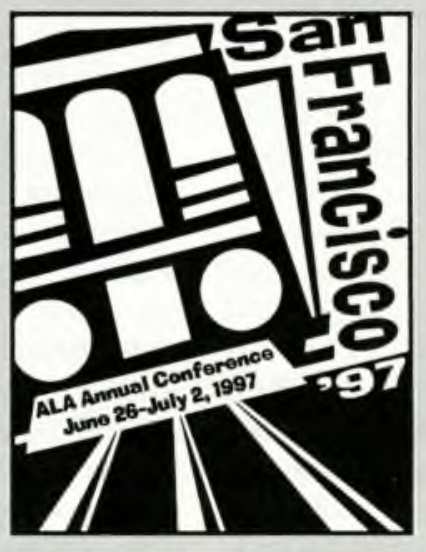
about information access and delivery on your campus.

\section{The speaker}

Ruth Michalecki is director of the Telecommunications Center at the University of $\mathrm{Ne}$ braska-Lincoln (UNL). She is responsible for the development and direction of telecommunications facilities and services for all locations within and outsicle the state where the appropriate systems for expanding campus information services is a responsibility librarians cannot ignore.

\section{The program}

"Telecommunications 101 for Librarians" will address: key telecommunications issues that are of importance to librarians; telecommunications networks that are found on campuses across the U.S.; how exchange and interexchange carriers function to deliver information; and telecommunications infrastructure.

\section{Why you should attend}

- To increase your understanding of telecommunications issues.

- To make better decisions about your campus information infrastructure.

- To hear how others are creating and managing campuswide information infrastructures.

- To learn the language that gets the results you need.

\section{Who should attend}

Whether you are the library director or a newcomer to the library staff, "Telecommunica-

university has a presence. Michalecki has been active in the areas of instructional development and lecturing. She developed an introductory workshop in managing telecommunications for ACUTA (Association of College \& University Telecommunications Administrators) and has tatught this course since 1985. Michalecki has also taught many courses at UNL, conclucted training programs for several corporations, and served as contributing editor for CommunicationNEWS.

\section{Registration information}

Registration for "Telecommunications 101 " is limited to the first 75 applicants. It will be held Friday June 27, in San Francisco, 8:00 a.m.-2:30 p.m. The fee includes a mini-lunch. Fees are $\$ 85$ for ACRL members, $\$ 120$ for ALA members, $\$ 155$ for non-ALA members, and $\$ 50$ for full-time students. Registrations received after May 15 will be assessed a $\$ 35$ late fee. Questions? Call (800) 545-2433, ext. 3248.

Refund requests must be submitted in writing prior to May 15 and are subject to a $\$ 35$ cancellation fee. Refunds will be processed and mailed after July 15 . No refunds will be made for cancellations after May 15. 